\title{
Peran Motivasi Belajar, Self-Efficacy, dan Dukungan Sosial Keluarga Terhadap Self-Regulated Learning pada Siswa
}

\author{
Ecep Mulyana \\ Fakultas Psikologi \\ Universitas Ahmad Dahlan \\ Jl. Kapas No.9, Semaki, Umbulharjo, \\ Kota Yogyakarta, Indonesia \\ Email: ecepmulyana862@gmail.com
}

\author{
Mujidin \\ Fakultas Psikologi \\ Universitas Ahmad Dahlan \\ J1. Kapas No.9, Semaki, Umbulharjo, \\ Kota Yogyakarta, Indonesia \\ Email: natabaya74@yahoo.com
}

\author{
Khoirudin Bashori \\ Fakultas Psikologi \\ Universitas Ahmad Dahlan \\ Jl. Kapas No.9, Semaki, Umbulharjo, \\ Kota Yogyakarta, Indonesia \\ Email: kbashori@uad.ac.id
}

\begin{abstract}
The purpose of this research is to know the role of learning motivation, self-efficacy and family support in self-regulated learning of the 11th grade of SMA N 2 Bantul's Students. There were as many as 248 students in the population of the 11th grade of SMA Negeri 2 Bantul and 72 of them were selected as samples using cluster random sampling technique. The data were collected by using learning motivation scale, self-efficacy, family support and self-regulated learning. The data analysis technique made use of multiple regression analysis and partial corelation technique. The regression analysis indicated positve correlation between learning moivation, self-efficacy and family support, and self-regulated learning with $\mathrm{F}$ value of $37.345, \mathrm{p}=$ $0.000(\mathrm{p}<0.05)$. There was positive impact of learning motivation to Self Regulated Learning with $\mathrm{t}=2.767$, $p=0.007(p<0.05)$. There was a positive role of Self Efficacy to Self-Regulated Learning with $t=3.532$ and $p=0.001(p<0.05)$, a positive role of Family Support to Self- Regulated Learning with $t=2.267$ and $p=$ 0.027 ( $\mathrm{p}<0.05$ ). This research can be used as a reference in the field of guidance and counseling, psychological counseling, or school psychology program within which it was mainly related to the increase in motivation, self-efficacy, social support families and self-regulated learning in learning activities of the students.
\end{abstract}

Keywords: learning motivation, self-efficacy, social support family, self regulated learning

Tujuan penelitian ini untuk mengetahui peran motivasi belajar, self-efficacy, dan dukungan sosial keluarga terhadap self-regulated learning pada siswa SMA Negeri 2 Bantul kelas XI. Populasi dalam penelitian ini siswa kelas XI SMA Negeri 2 Bantul sejumlah 248 orang dengan sampel 72 orang yang ditentukan melalui teknik cluster random sampling. Pengumpulan data menggunakan skala motivasi belajar, self-efficacy, dukungan sosial keluarga, dan self-regulated learning. Teknik analisis data yang digunakan adalah analisis regresi berganda dan teknik korelasi parsial. Hasil analisis regresi menunjukkan adanya peran yang positif antara motivasi belajar, self-efficacy, dan dukungan sosial keluarga terhadap self-regulated learning dengan $\mathrm{F}$ hitung sebesar 37,345, $\mathrm{p}=0.000(\mathrm{p}<0,05)$. Ada peran positif motivasi belajar terhadap dengan $\mathrm{t}=2,767, \mathrm{p}=$ 0,007 (self regulated learning $\mathrm{p}<0.05$ ). Ada peran positif self-efficacy terhadap self regulated learning dengan $\mathrm{t}=3,532$ dan $\mathrm{p}=0,001(\mathrm{p}<0.05)$. Ada peran positif dukungan sosial keluarga terhadap self regulated learning dengan $t=2,267$ dan $p=0,027(p<0,05)$. Penelitian ini dapat dijadikan tambahan referensi dalam bidang bimbingan dan konseling, psikologi konseling, atau psikologi sekolah terutama yang berhubungan dengan program peningkatan motivasi belajar, self efficacy, dukungan sosial keluarga, dan self regulated learning dalam proses belajar siswa.

Kata kunci: motivasi belajar, self-efficacy, dukungan sosial keluarga, self regulated learning 


\section{Pendahuluan}

Proses pembelajaran dapat terlaksana dengan baik, apabila tercipta susana kelas yang kondusif. Peserta didik mampu mengikuti pelajaran sebagaimana yang telah ditetapkan sekolah. Menerima pelajaran dan pengetahuan adalah hak siswa yang harus diberikan sekolah. Pembelajaran pada intinya merupakan sebuah sistem dimana ada proses mengubah peserta didik (masukan/input) diolah atau diproses dalam kegiatan pembelajaran, lalu hasilnya berupa lulusan yang disebut output (Sutikno, 2004).

Pengaturan diri bagi siswa akan membantu siswa dalam proses belajar. Mereka yang menggunakan pengaturan diri yang baik akan mudah meraih prestasi. Individu dengan pengaturan diri yang baik akan mau dan mampu untuk belajar dengan inisiatif sendiri, dengan atau tanpa bantuan pihak lain dalam hal penentuan tujuan belajar, metode belajar, dan evaluasi hasil belajar.

Self-regulated learning adalah sebuah konsep mengenai bagaimana individu menjadi regulator atau pengatur bagi belajarnya sendiri. Konsep selfregulated learning bukan kemampuan mental seperti inteligensi atau kemampuan akademik tetapi lebih kepada proses mengarahkan diri untuk mengubah kemampuan mental menjadi kemampuan akademik (Zimmerman \& MartinezPons, 1988).

Zimmerman dan Martinez-Pons (2001) menjelaskan bahwa dalam proses belajar, seorang siswa akan memperoleh prestasi belajar yang baik bila ia menyadari, bertanggungjawab, dan mengetahui cara belajar yang efisien. Siswa demikian selanjutnya diistilahkan Zimmerman sebagai seorang siswa yang belajar dengan regulasi diri (self regulated learner).

Salah satu faktor yang berpengaruh terhadap self regulated learning adalah motivasi. Motivasi berkaitan dengan emosi, sehingga dapat mendorong individu untuk mencapai tujuan tertentu. Seberapa kuat motivasi yang dimiliki individu akan banyak menentukan terhadap kualitas perilaku yang ditampilkannya, baik dalam konteks belajar, maupun dalam kehidupan lainnya.

Menurut Hamalik (2005) motivasi adalah perubahan energi dalam diri (pribadi) seseorang yang ditandai dengan timbulnya perasaan dan reaksi untuk mencapai tujuan. Hamalik lebih lanjut menjelaskan motivasi mempunyai dua komponen, yakni komponen dalam (inner component) dan komponen luar. Komponen dalam adalah perubahan dalam diri seseorang, keadaan merasa tidak puas, dan ketegangan psikologis. Komponen luar adalah apa yang diinginkan seseorang, tujuan yang menjadi arah kelakuannya. Jadi, komponen dalam adalah kebutuhan-kebutuhan yang ingin dipuaskan, sedangkan komponen luar ialah tujuan yang hendak dicapai.

Faktor lain yang berpengaruh terhadap Self Regulated Learning adalah Self efficacy. Bandura (Friedman \& Schustack, 2006), menyatakan bahwa self efficacy adalah ekspektasi atau keyakinan (harapan tentang seberapa jauh seseorang mampu melakukan satu perilaku dalam suatu situasi tertentu). Self efficacy yang positif adalah keyakinan untuk mampu melakukan perilaku yang dimaksud. Tanpa self efficacy (keyakinan tertentu yang sangat situasional), orang bahkan enggan mencoba melakukan suatu perilaku.

Faktor lain yang berpengaruh terhadap Self Regulated Learning adalah dukungan sosial. Dukungan sosial adalah sebuah cara untuk menunjukkan kasih sayang, kepedulian, dan penghargaan untuk orang lain. Menurut Ritter (Smet, 1994) dukungan sosial (social support) mengacu pada bantuan emosional, instrumental, dan finansial yang diperoleh dari jaringan sosial seseorang. Dukungan sosial merupakan kenyamanan psikis dan emosional yang diberikan kepada individu oleh keluarga, teman, rekan, dan yang lainnya.

Peserta didik yang belajar dengan regulasi diri bukan hanya tahu tentang apa yang dibutuhkan oleh setiap tugas, tetapi mereka juga dapat menerapkan strategi yang dibutuhkan. Mereka dapat membaca secara sekilas ataupun secara seksama. Mereka dapat menggunakan berbagai strategi ingatan atau mengorganisasikan materinya. Namun pada kenyataannya, fenomena yang terjadi tidak semua peserta didik menyadari bahwa dalam proses belajar diperlukan pengaturan dan pengendalian diri agar proses belajar efisien dan mencapai sasaran yang diinginkan, yaitu pengusaan materi dan mencapai prestasi yang tinggi.

Penelitian ini bertujuan untuk mengetahui peran motivasi belajar, self-efficacy, dan dukungan sosial keluarga terhadap self-regulated learning pada siswa. Melalui self-regulated learning siswa dapat belajar mengembangkan kemampuan untuk mengatur diri dalam belajar sehingga mampu 


\section{MOTIVASI BELAJAR, SELF-EFFICACY, DUKUNGAN SOSIAL KELUARGA, SELF} REGULATED LEARNING

mencapai pengaturan belajar yang baik. Penelitian ini dapat dijadikan tambahan referensi dalam bidang bimbingan dan konseling, psikologi konseling, atau psikologi sekolah terutama yang berhubungan dengan program peningkatan motivasi belajar, self efficacy, dukungan sosial keluarga, dan self regulated learning dalam optimalisasi proses belajar siswa.

\section{Kajian Literatur}

\section{Self Regulated Learning.}

Peserta didik membutuhkan kemandirian dalam proses belajar. Salah satu yang berpangaruh terhadap kemandirian belajar peserta didik adalah self regulated learning. Self regulated learning didefinisikan sebagai tingkatan dimana partisipan secara aktif melibatkan metakognisi, motivasi, dan perilaku dalam proses belajar (Zimmerman \& Martinez-Pons, 2001).

Menurut Valle et al., (Latipah, 2010) self regulated learning menggarisbawahi pentingnya otonomi dan tanggung jawab pribadi dalam kegiatan belajar. Dalam proses pembelajaran, siswa yang memiliki self regulated learning membangun tujuan-tujuan belajar, mencoba memonitor, meregulasi, dan mengontrol kognisi, motivasi, dan perilakunya untuk mengontrol tujuan-tujuan yang telah dibuat.

Regulasi diri adalah proses dimana seseorang dapat mengatur pencapaian dan aksi mereka sendiri. Menentukan target untuk diri mereka, mengevaluasi kesuksesan mereka saat mencapai target tersebut, dan memberikan penghargaan pada diri mereka sendiri karena telah mencapai tujuan tersebut. Konstruk regulasi diri menitikberatkan pada kontrol internal (inter personal) perilaku (Friedman \& Schustack, 2006).

Menurut Bandura (1997) dalam teori kognisi sosial, manusia merupakan hasil struktur kausal yang interdependen dari aspek pribadi (person), perilaku (behavior), dan lingkungan (environment). Ketiga aspek tersebut merupakan aspek-aspek determinan dalam Self Regulated Learning. Ketiga aspek determinan ini saling berhubungan sebab akibat, dimana person berusaha untuk meregulasi diri (self-regulated), hasilnya berupa kinerja atau perilaku, dan perilaku tersebut berdampak pada perubahan lingkungan dan demikian seterusnya.

Cobb (2003) menyatakan bahwa self regulated learning dipengaruhi oleh banyak faktor, diantaranya adalah self efficacy, motivasi dan tujuan (goals). Self efficacy merupakan penilaian individu terhadap kemampuan atau kompetensinya untuk melakukan suatu tugas, mencapai suatu tujuan, atau mengatasi hambatan dalam belajar. Motivasi yang dimiliki peserta didik secara positif berhubungan dengan self regulated learning. Motivasi dibutuhkan peserta didik untuk melaksanakan strategi yang akan mempengaruhi proses belajar. Tujuan (goals) merupakan penetapan tujuan apa yang hendak dicapai seseorang. Goals memiliki dua fungsi dalam self regulated learning yaitu menuntun peserta didik untuk memonitor dan mengatur usahanya dalam arah yang spesifik. Selain itu goals juga merupakan kriteria bagi peserta didik untuk mengevaluasi performansi mereka.

Dimyati dan Mudjiono (2006) menjelaskan motivasi belajar adalah sesuatu kekuatan mental yang mendorong terjadinya belajar. Motivasi dipandang sebagai dorongan mental yang menggerakkan dan mengarahkan perilaku manusia, termasuk perilaku belajar. Menurut Aritonang (2008) Motivasi belajar siswa meliputi beberapa dimensi, yaitu: ketekunan dalam belajar, ulet dalam menghadapi kesulitan, minat dan ketajaman perhatian dalam belajar, berprestasi dalam belajar, mandiri dalam belajar.

Bandura (Feist \& Feist, 2008) mendefinisikan self-efficacy sebagai keyakinan manusia pada kemampuan mereka untuk melatih sejumlah ukuran pengendalian terhadap fungsi diri mereka dari kejadian-kejadian di lingkungannya, "dan dia juga yakin kalau" self-efficacy adalah fondasi keagenan manusia. Menurut Baron \& Byrne (1997) self efficacy adalah bagian dari self concept yang merupakan keyakinan seseorang akan kemampuan untuk menangani tugas secara efektif dan melakukan tindakan yang diperlukan untuk menangani masalah.

Menurut Bandura (Veleyutham, S. et al., 2012) teori self-efficacy yang berpengaruh terhadap perilaku siswa adalah keyakinan yang mereka pegang tentang kemampuan mereka. Siswa lebih cenderung untuk belajar jika mereka percaya bahwa mereka mampu untuk belajar dan mencapai hasil yang diinginkan.

Bandura (1997) mengemukakan tiga aspek self efficacy, antara lain Magnitude, Generality, dan Strength. Magnitude berkaitan dengan derajat kesulitan tugas dimana individu merasa mampu 
atau tidak untuk melakukannya, sebab kemampuan diri individu berbeda-beda. Konsep dalam dimensi ini terletak pada keyakinan individu atas kemampuannya terhadap tingkat kesulitan tugas. Generality berkaitan dengan Kemampuan mengevaluasi diri, Keyakinan diri, Banyaknya tugas yang mampu dikerjakan, Orientasi tujuan dan Locus of control internal (pengendalian diri). Strength berkaitan dengan tingkat kekuatan dari keyakinan atau pengharapan individu mengenai kemampuannya.

Baron dan Byrne (2003) menjelaskan bahwa dukungan sosial adalah kenyamanan secara fisik dan psikologis yang diberikan oleh teman atau anggota keluarga. Dukungan sosial juga dapat dilihat dari banyaknya kontak sosial yang terjadi atau yang dilakukan individu dalam menjalin hubungan dengan sumber-sumber yang ada di lingkungan. Penjelasan laian dikemukakan oleh Rook (Smet, 1994) bahwa dukungan sosial sebagai salah satu fungsi pertalian sosial yang menggambarkan tingkat dan kualitas umum dari hubungan interpersonal yang akan melindungi individu dari konsekuensi stress. Dukungan sosial yang diterima dapat membuat individu merasa tenang, diperhatikan, timbul percaya diri dan kompeten.

Sears (Bukhori, 2012) menjelaskan bahwa dukungan sosial adalah suatu hubungan interpersonal dimana individu memberikan bantuan kepada individu lain dan bantuan yang diberikan berupa partisipasi, emansipasi, motivasi, penyediaan informasi, dan penghargaan atau penilaian terhadap individu. Sejalan dengan Sarason (Bukhori, 2012) mengemukakan bahwa dukungan sosial merupakan suatu keadaan yang bermanfaat bagi individu yang diperoleh dari orang lain yang dapat dipercaya. Selanjutnya menurut Sarafino (2006) dukungan sosial memiliki empat aspek, yaitu: Dukungan emosional, Dukungan penghargaan, Dukungan instrumental, dan Dukungan informasi. Dukungan emosional melibatkan ekspresi rasa empati dan perhatian terhadap individu, sehingga individu tersebut merasa nyaman, dicintai dan diperhatikan. Dukungan penghargaan melibatkan ungkapan hormat (penghargaan) positif untuk orang tersebut, dorongan maju atau persetujuan. Dukungan instrumental melibatkan bantuan langsung, misalnya yang berupa bantuan finansial atau bantuan dalam mengerjakan tugas-tugas tertentu.
Dukungan informasi ini dapat berupa pemberian nasihat, petunjuk, saran-saran atau umpan balik.

Berdasarkan pendapat para ahli di atas, dapat dimaknai bahwa self regulated learning dipengaruhi oleh banyak faktor, diantaranya adalah self efficacy, motivasi dan tujuan (goals), serta dukungan sosial.

\section{Metode Penelitian}

Populasi pada penelitian ini adalah siswa SMA N 2 Bantul Kelas XI yang berjumlah 9 kelas jumlah keseluruhan 248 siswa. Adapun teknik sampling dalam penelitian ini adalah dengan menggunakan Cluster randem sampling. Peneliti menggunakan 9 gulungan kertas yang sudah ditulis nama kelasnya, kemudian diambil 3 buah gulungan secara acak selanjutnya ditetapkan sebagai kelas try out, sedangkan 6 gulungan kertas digunakan untuk penelitian. Sampel pada penelitian ini berjumlah 72 orang.

Jenis data yang digunakan dalam penelitian ini adalah data kuantitatif. Instrumen pengambilan data dalam penelitian ini menggunakan skala motivasi belajar yang berjumlah 30 item, self efficacy yang berjumlah 30 item, dukungan sosial keluarga yang berjumlah 32 item, dan self regulated learning yang berjunlah 30 item. Skala-skala tersebut terlebih dahulu diuji coba untuk mengetahui reliabilitas dan validitasnya. Teknik analisis data yang digunakan adalah analisis regresi berganda dan teknik korelasi parsial. Teknik analisis data ini digunakan untuk menguji korelasi antar variabel penelitian.

\section{Hasil Penelitian dan Pembahasan}

Data hasil penelitian tentang peran motivasi belajar, self efficacy, dan dukungan sosial keluarga terhadap self regulated learning pada siswa kelas XI SMA N 1 Bantul dikategorisasikan menjadi tinggi, sedang, dan rendah yang dipaparkan dalam tabel 1

Tabel 1.

Kategorisasi Motivasi Belajar

\begin{tabular}{llllll}
\hline & & $\begin{array}{l}\text { Frequ- } \\
\text { ency }\end{array}$ & $\begin{array}{l}\text { Per- } \\
\text { cent }\end{array}$ & $\begin{array}{l}\text { Valid } \\
\text { Percent }\end{array}$ & $\begin{array}{l}\text { Cumulative } \\
\text { Percent }\end{array}$ \\
\hline Valid & Tinggi & 12 & 16.7 & 16.7 & 16.7 \\
& Sedang & 53 & 73.6 & 73.6 & 90.3 \\
& Rendah & 7 & 9.7 & 9.7 & 100.0 \\
& Total & 72 & 100.0 & 100.0 & \\
\hline
\end{tabular}




\section{REGULATED LEARNING}

Selanjutnya mengenai profil self efficacy siswa kelas XI SMA N 2 bantul dapat dilihat dalam tabel 2.

Tabel 2.

Kategorisasi Self Efficacy

\begin{tabular}{|c|c|c|c|c|c|}
\hline & & $\begin{array}{l}\text { Frequ- } \\
\text { ency }\end{array}$ & $\begin{array}{l}\text { Per- } \\
\text { cent }\end{array}$ & $\begin{array}{l}\text { Valid } \\
\text { Percent }\end{array}$ & $\begin{array}{l}\text { Cumulative } \\
\text { Percent }\end{array}$ \\
\hline \multirow[t]{4}{*}{ Valid } & Tinggi & 9 & 12.5 & 12.5 & 12.5 \\
\hline & Sedang & 57 & 79.2 & 79.2 & 91.7 \\
\hline & Rendah & 6 & 8.3 & 8.3 & 100.0 \\
\hline & Total & 72 & 100.0 & 100.0 & \\
\hline
\end{tabular}

Berikutnya akan dipaparkan profil dukungan sosial keluarga siswa kelas XI SMA N 2 bantul dapat dilihat dalam tabel 3.

Tabel 3.

Kategorisasi Dukungan Sosial Keluarga

\begin{tabular}{|c|c|c|c|c|c|}
\hline & & $\begin{array}{l}\text { Frequ- } \\
\text { ency }\end{array}$ & $\begin{array}{l}\text { Per- } \\
\text { cent }\end{array}$ & $\begin{array}{l}\text { Valid } \\
\text { Percent }\end{array}$ & $\begin{array}{l}\text { Cumulative } \\
\text { Percent }\end{array}$ \\
\hline \multirow[t]{4}{*}{ Valid } & Tinggi & 13 & 18.1 & 18.1 & 18.1 \\
\hline & Sedang & 49 & 68.1 & 68.1 & 86.1 \\
\hline & Rendah & 10 & 13.9 & 13.9 & 100.0 \\
\hline & Total & 72 & 100.0 & 100. & \\
\hline
\end{tabular}

Kemudian pada tabel 4 dipaparkan profil self regulated learning siswa kelas XI SMA N 2 bantul.

Tabel 4.

Kategorisasi Self Regulated Learning

\begin{tabular}{|c|c|c|c|c|c|}
\hline & & $\begin{array}{l}\text { Frequ } \\
\text {-ency }\end{array}$ & $\begin{array}{l}\text { Per- } \\
\text { cent }\end{array}$ & $\begin{array}{l}\text { Valid } \\
\text { Percent }\end{array}$ & $\begin{array}{l}\text { Cumulative } \\
\text { Percent }\end{array}$ \\
\hline \multirow[t]{4}{*}{ Valid } & Tinggi & 14 & $\begin{array}{l}19.4 \\
\end{array}$ & 19.4 & 19.4 \\
\hline & Sedang & 51 & 70.8 & 70.8 & 90.3 \\
\hline & Rendah & 7 & 9.7 & 9.7 & 100.0 \\
\hline & Total & 72 & 100.0 & 100.0 & \\
\hline
\end{tabular}

Hasil uji normalitas menggunakan One Sampel Kolmogorov Smirnov Test diperoleh data untuk variabel Motivasi Belajar nilai asymp sig 0,715, variabel Self Efficacy nilai asymp sig 0,653 , variabel dukungan sosial kealurga nilai asymp sig 0,415, dan variabel Self Regulated Learning nilai asymp sig 0,183 . Oleh karena keempat variabel tersebut nilai asymp sig nya lebih besar dari 0,05 maka dapat disimpulkan bahwa data variabel-variabel tersebut berdistribusi normal.

Hasil uji linieritas variabel Motivasi Belajar dengan Self Regulated Learning menunjukkan bahwa nilai $\mathrm{F}$ sebesar 78,648 dengan sig 0,000. Variabel Self Efficacy dengan Self Regulated Learning menunjukkan bahwa nilai $\mathrm{F}$ sebesar 86,937 dengan signifikansi 0,000. Dukungan sosial keluarga dengan Self Regulated Learning nilai $F$ sebesar 27,228 dengan sig 0,000. Oleh karena nilai sig-sig tersebut kurang dari 0,05 maka dapat disimpulkan bahwa hubungan antara variabel bebas dengan terikat bersifat linear.

Hasil analisis uji multikolinieritas diketahui nilai variance inflation factor (VIF) dari tiga variabel yaitu Motivasi Belajar 2,370, Self Efficacy sebesar 2,205, dan Dukungan Sosial Keluarga sebesar 1,443 yang menunjukkan lebih kecil dari 5, sehingga bisa diduga bahwa antar variabel independent tidak terjadi persoalan multikolinearitas.

Hasil analisis uji heteroskedastisitas diperoleh koefisien korelasi Rho antara Motivasi Belajar dengan absolut residu adalah sebesar 0,18 dengan sig 0,882. Self Efficacy dengan absolut residu adalah sebesar -0,19 dengan sig 0,874 . Dukungan Sosial Keluarga dengan absolut residu adalah sebesar $-0,103$ dengan sig 0,979. Oleh karena nilai sig tersebut lebih besar dari 0,05 maka dapat disimpulkan bahwa tidak terjadi heteroskedastisitas pada variabel bebas.

Hasil analisis korelasi ganda diperoleh angka $\mathrm{R}$ sebesar 0,789 . Hal ini menunjukkan bahwa hubungan Motivasi Belajar, Self Efficacy, dan Dukungan Sosial Keluarga terhadap Self Regulated Learning pada tingkat kuat. Dari hasil analisis regresi nilai koefisien determinasi $\mathrm{R}^{2}$ (Adjusted $R$ Square) diperoleh angka sebesar 0,606 atau $(60,6 \%)$. Artinya variansi dalam Self Regulated Learning dapat dijelaskan oleh Motivasi Belajar, Self Efficacy, dan Dukungan Sosial Keluarga melalui model sebesar $60,6 \%$, sisanya $(39,4 \%)$ berasal dari variabel lain.

Hasil uji hipotesis dengan menggunakan teknik regresi berganda diperoleh harga $\mathrm{F}$ hitung sebesar 37,345 dengan Sig. $=0.000$. Oleh karena nilai sig. $<0,05(0,000<0,05)$ maka Ho ditolak yang artinya Motivasi Belajar, Self-Efficacy, dan Dukungan Sosial Keluarga secara bersama-sama 
memiliki peran positif yang signifikan terhadap Self Regulated Learning. Selanjutnya, persamaan regresi linier berganda yang diperoleh disajikan pada tabel 5 .

Tabel 5.

Persamaan Regresi Linier Berganda

\begin{tabular}{llllll}
\hline \multirow{6}{*}{ Model } & $\begin{array}{l}\text { Coefficients } \\
\text { Unstan- } \\
\text { dardized } \\
\text { Coefficients } \\
\text { B }\end{array}$ & $\begin{array}{l}\text { Standar-dized } \\
\text { Coefficients }\end{array}$ & $T$ & Sig \\
& & $\begin{array}{l}\text { Std. } \\
\text { Error }\end{array}$ & Beta & & \\
\hline Constant & 23.340 & 6.173 & & 3.781 & .000 \\
Motivasi & .299 & .108 & .317 & 2.767 & .007 \\
$\begin{array}{l}\text { Belajar } \\
\text { Self Efficacy }\end{array}$ & .300 & .085 & .391 & 3.532 & .001 \\
$\begin{array}{l}\text { Duk. Sosial } \\
\text { Kel. } \\
\text { a. Dependent } \text { Variable: Self Regulated Learning }\end{array}$ & .120 & .053 & .203 & 2.267 & .027 \\
\hline
\end{tabular}

Berdasar Tabel 5 Model persamaan regresi linier berganda adalah $Y^{\prime}=\mathbf{2 3 , 3 4 0}+\mathbf{0 , 2 9 9}$ X1 + 0,300 X2 + 0,120 X3. Konstanta sebesar 23,340, koefisien X1 (Motivasi Belajar) sebesar 0,299, koefisien X2 (Self Efficacy) sebesar 0,300, dan koefisien X3 (Dukungan Sosial Keluarga) sebesar 0,120. Persamaan regresi tersebut berarti bahwa Motivasi Belajar, SelfEfficacy, dan Dukungan Sosial Keluarga secara bersama-sama memiliki peran yang signifikan terhadap Self Regulated Learning. Adanya peningkatan X1 (Motivasi Belajar), X2 (Self Efficacy), dan X3 (Dukungan Sosial Keluarga), maka akan diikuti oleh peningkatan terhadap Self Regulated Learning (Y).

Berdasarkan penelitian ini ada tiga faktor yang mempengaruhi Self Regulated Learning, yaitu Motivasi Belajar, Self Efficacy, dan Dukungan Sosial Kelaurga. Motivasi Belajar merupakan salah satu faktor yang turut diperhitungkan dalam mempengaruhi Self Regulated Learning. Kemampuan self-regulated learning ini tidak dapat berkembang dengan sendirinya. Dibutuhkan dorongan atau keinginan dari dalam diri siswa untuk dapat berhasil dan mencapai prestasi yang diinginkan. Motivasi merupakan salah satu aspek penting dalam proses self-regulated learning. Self regulated learning tidak akan berjalan tanpa disertai motivasi diri untuk melakukan suatu tindakan (Zimmerman, 2000).

Siswa yang memiliki motivasi belajar tinggi akan memiliki kemampuan self-regulated learning yang tinggi. Siswa akan berusaha mencoba setiap tugas yang diberikan meskipun sulit untuk dikerjakan. Siswa yang memiliki motivasi belajar menginginkan keberhasilan, dan ketika mereka gagal akan melipat gandakan usaha mereka sehingga dapat berhasil. Mereka terdorong untuk merencanakan, mengatur, memonitor, mengevaluasi bahkan memanfaatkan lingkungan untuk mendukung aktivitas belajarnya.

Sebaliknya siswa yang motivasi belajar rendah akan memiliki kemampuan self regulated learning yang rendah, dimana siswa akan merasa enggan melakukan tugas yang diberikan apabila ia tahu bahwa dirinya tidak mampu melakukannya, tanpa ada usaha. Keengganan tersebut membuat siswa tidak mampu merencanakan atau mengatur pikiran, perilaku, dan emosinya yang menyebabkan siswa lebih cenderung defensif seperti memilih membolos, menyontek dan sebagainya.

Hasil analisis secara parsial antara variabel motivasi belajar dengan self regulated learning diperoleh $\mathrm{t}=2,767$ dan Sig. $=0,007$. Oleh karena nilai sig. $<0,05(0,007<0,05)$ maka Ho ditolak dan Ha diterima yang artinya secara parsial variabel motivasi belajar berpengaruh secara signifikan terhadap self regulated learning. Hal ini menunjukkan bahwa motivasi belajar mempunyai peran positif terhadap self regulated learning. Semakin tinggi motivasi belajar, maka akan semakin tinggi pula self regulated learning. Semakin rendah motivasi belajar, maka akan semakin rendah pula self regulated learning.

Motivasi belajar yang baik menjadikan siswa menyukai pekerjaan-pekerjaan yang lebih menantang serta mencari cara yang baru dan kreatif, sehingga mendorong siswa untuk merencanakan langkah-langkah yang akan dilakukan untuk menyelesaikan permasalahan yang dihadapi. Selain itu rasa tanggungjawab terhadap permasalahan yang dihadapi pun mendorong siswa untuk mengatur pikiran, perilaku dan emosinya untuk menyelesaikan masalah tersebut (Inayah, 2013).

Hasil analisis kategorisasi menunjukkan bahwa 53 subyek penelitian atau $73,6 \%$ dari 72 subyek penelitian memiliki tingkat motivasi belajar yang sedang. Hal ini menunjukkan bahwa pada umumnya subyek cukup memiliki dorongan dan 


\section{MOTIVASI BELAJAR, SELF-EFFICACY, DUKUNGAN SOSIAL KELUARGA, SELF REGULATED LEARNING}

keinginan secara mandiri untuk belajar. Siswa yang memiliki motivasi belajar yang tinggi akan berusaha mengoptimalkan segala kemampuannya untuk menyelesaikan tugas sekolah. Seberapa kuat motivasi yang dimiliki individu akan banyak menentukan terhadap kualitas perilaku yang ditampilkannya, baik dalam konteks belajar, bekerja maupun dalam kehidupan lainnya.

Faktor lain yang berpengruh terhadap self regulated learning adalah self efficacy. Seperti dijelaskan sebelumnya (Muharrani, 2012), mengemukakan self regulated learning akan lebih berhasil apabila didukung oleh self-efficacy, yaitu keyakinan yang ada pada individu bahwa ia mampu untuk belajar dan menghasilkan harapan-harapan personal sebagai akibat dari proses belajar. Selfefficacy mengacu pada persepsi tentang kemampuan individu untuk mengorganisasi dan mengimplementasi tindakan untuk menampilkan kecakapan tertentu.

Hasil analisis secara parsial antara variabel selfefficacy dengan self regulated learning diperoleh $\mathrm{t}$ $=3,532$ dan Sig. $=0,001$. Oleh karena nilai sig. < $0,05(0,001<0,05$, maka Ho ditolak dan $\mathrm{Ha}$ diterima yang artinya secara parsial variabel selfefficacy berpengaruh secara signifikan terhadap Self Regulated Learning. Hal ini menunjukkan bahwa self-efficacy mempunyai peran positif terhadap self regulated learning. Semakin tinggi self efficacy, maka akan semakin tinggi pula Self Regulated Learning. Semakin rendah self efficacy, maka akan semakin rendah pula self regulated learning.

Siswa yang memiliki self regulated learning yang tinggi dapat mengorganisir pekerjaan mereka, menetapkan tujuan, mencari bantuan ketika diperlukan, menggunakan strategi kerja yang efektif, mengatur waktu mereka untuk belajar, dan memiliki efikasi diri. Adanya efikasi diri, siswa dapat mengontrol emosinya, menentukan tindakan berdasarkan pandangan pribadi, berani mengambil keputusan tentang tingkah laku pribadi serta pengambilan keputusan dalam pemecahan masalah, dapat mengurangi ketergantungan pada orang lain, dapat menentukan baik-buruk dan benar-salah.

Menurut (Baron \& Byrne, 1997) individu yang memiliki self efficacy tinggi akan mengarahkan individu pada prestasi yang lebih baik dalam dalam berbagai bidang karena self efficacy tersebut mengaktifkan perubahan psikologis untuk mengurangi rasa sakit dan membuat stress lebih dapat ditoleransi.
Hasil analisis kategorisasi menunjukkan bahwa 57 siswa atau $79,2 \%$ dari 72 subyek penelitian mempunyai self efficacy yang sedang. Hal ini menunjukkan bahwa subyek secara umum sudah cukup mempunyai kemampuan dan keyakinan dirinya untuk menyelesaikan suatu tugas. Kemampuan dan keyakinan tersebut menimbulkan berkembangnya sikap belajar yang positif.

Individu yang memiliki self efficacy tinggi akan lebih aktif dan lebih giat dalam berusaha serta lebih berani dalam menetapkan tujuan yang ingin dicapai. Individu yang mempunyai self efficacy mempunyai motivasi yang tinggi dan lebih berani menetapkan tujuan yang ingin dicapai sehingga mempunyai self regulated lerning yang tinggi.

Faktor lain yang berpengaruh terhadap self regulated lerning adalah dukungan sosial keluarga. Dukungan sosial menjadi hal yang mempengaruhi self regulated learning, karena siswa membutuhkan dukungan eksternal dari keluarganya. Dukungan sosial dari keluarganya yang tinggi akan meningkatkan self regulated learning. Orang yang mendapat dukungan sosial dari keluarga yang tinggi, maka akan mendapatkan dukungan emosional, penghargaan, instrumental, dan informatif dari keluarga.

Menurut Hurlock (2001) dukungan dari keluarga yang berupa penerimaan, perhatian dan rasa percaya akan meningkatkan kebahagiaan dalam diri remaja. Kebahagiaan yang diperoleh remaja menyebabkan remaja termotivasi untuk terus berusaha mencapai tujuannya. Remaja juga mempunyai rasa percaya diri dalam menyelesaikan tugas yang dihadapi.

Hasil analisis secara parsial antara variabel Dukungan Sosial Keluarga dengan self regulated learning diperoleh $\mathrm{t}=2,267$ dan Sig. $=0,027$. Oleh karena nilai sig. $<0,05(0,027<0,05)$, maka Ho ditolak dan Ha diterima yang artinya secara parsial variabel dukungan sosial keluarga berpengaruh secara signifikan terhadap self regulated learning. Hal ini menunjukkan bahwa Dukungan Sosial Keluarga mempunyai peran positif terhadap Self Regulated Learning. Semakin tinggi dukungan sosial keluarga, maka akan semakin tinggi pula self regulated learning. Semakin rendah dukungan sosial keluarga, maka akan semakin rendah pula self regulated learning.

Individu dengan dukungan sosial yang tinggi akan mempunyai pikiran lebih positif terhadap situasi yang sulit dibandingkan dengan individu 
yang memiliki tingkat dukungan sosial rendah. Menerima berbagai jenis dukungan sosial dapat membantu sesorang dalam mengatur dirinya sendiri. Hasil analisis kategorisasi menunjukkan bahwa 49 siswa atau $(68,1 \%)$, dari 72 subyek penelitian mempunyai tingkat dukungan sosial keluarga yang sedang. Hal ini menunjukkan bahwa subyek sudah cukup memilki dukungan sosial dari keluarga untuk belajar. Dukungan dari kelarga yang tinggi akan membantu siswa untuk mengatur belajarnya, karena individu memperoleh kehangatan, perhatian, dorongan, arahan, dan bimbingan dari keluarga apabila individu yang bersangkutan mengalami kesulitan dalam belajar.

Motivasi belajar, self efficacy, dan dukungan sosial keluarga memberikan sumbangan efektif terhadap self regulated learning sebesar 0,606 atau $(60,6 \%)$ dengan rincian motivasi belajar sebesar $22,0 \%$, self efficacy sebesar $27,4 \%$, dan dukungan sosial kelurga sebesar $11,2 \%$. Artinya terdapat $60,6 \%$ peran motivasi belajar, self efficacy, dan dukungan sosial keluarga terhadap self regulated learning. Hal ini berarti terdapat $39,4 \%$ variabel lain selain motivasi belajar, self efficacy, dan dukungan sosial yang berperan terhadap self regulated learning. Adapun sumbangan relatif yang mempunyai kontribusi terbesar adalah variabel Self Efficacy (X2) yaitu sebesar 45,3\%, kemudian motivasi belajar (x1) dengan kontribusi 36,3\% dan variabel dukungan sosial keluarga (X3) memilki kontribusi $18,4 \%$.

\section{Simpulan}

Ada peran positif motivasi belajar, self-efficacy, dan dukungan sosial keluarga terhadap self regulated learning secara bersama-sama. Semakin tinggi motivasi belajar, self-efficacy, dan dukungan sosial keluarga, maka akan semakin tinggi pula self regulated learning. Sebaliknya semakin rendah motivasi belajar, self-efficacy, dan dukungan sosial keluarga, maka akan semakin rendah pula self regulated learning.

Ada peran positif motivasi belajar terhadap self regulated learning. Semakin tinggi motivasi belajar, maka akan semakin tinggi pula self regulated learning. Sebaliknya semakin rendah motivasi belajar, maka akan semakin rendah pula self regulated learning.

Ada peran positif self-efficacy terhadap self regulated learning. Semakin tinggi self-efficacy, maka akan semakin tinggi pula self regulated learning. Sebaliknya semakin rendah self-efficacy, maka akan semakin rendah pula self regulated learning.

Ada peran positif dukungan sosial keluarga terhadap self regulated learning. Semakin tinggi dukungan sosial keluarga, maka akan semakin tinggi pula self regulated learning. Sebaliknya semakin rendah dukungan sosial keluarga, maka akan semakin rendah pula self regulated learning.

Berdasarkan hasil yang diperoleh dari penelitian yang telah dilakukan, maka dapat ). Penelitian ini dapat dijadikan referensi dalam bidang bimbingan dan konseling, psikologi konseling, atau psikologi sekolah terutama yang berhubungan dengan program peningkatan motivasi belajar, self efficacy, dukungan sosial keluarga, dan self regulated learning dalam proses belajar siswa.

\section{Referensi}

Aritonang, K. T. (2008). Minat dan Motivasi dalam Meningkatkan Hasil Belajar Siswa. Jurnal Pendidikan, 11-21.

Bandura, A. (1997). Self Efficacy: The Exercise of Control. New York: Freeman.

Baron, R dan Bryne, D. (2003). Psikologi Sosial: Edisi Kesepuluh Jilid I. Penerjemah: Ratna Djuwita, Melania Meitty Parman, Dyah Yusmina, Lita P. Lunanta. Jakarta : Erlangga.

Baron, R \& Byrne, D. (1997). Social Psychology. $8^{\text {th }}$ Edition. Massachussets: A Viacom Company.

Bukhori, B. (2012). Hubungan Kebermaknaan Hidup dan Dukungan Sosial Keluarga dengan Kesehatan Mental Narapidana (Studi Kasus Nara Pidana Di Kota Semarang). Jurnal Ad Din. 4. 1-19.

Cobb, R. (2003). The Relationship Between SelfRegulated Learning Behaviors and Academic Performance In Web-Based Courses. Desertation. Virginia: Faculty of Virginia Polytechnic Institute and State University.

Dimyati dan Mudjiono. (2006). Belajar dan Pembelajaran. Jakarta: Rineka Cipta.

Feist, J., \& Feist, G. J. (2008). Theories of Personality. Edisi Keenam. Penerjemah: Yudi Santoso. Yogyakarta: Pustaka Pelajar.

Friedman, H. S., \& Schustack, M. W. (2006). Kepribadian Teori Klasik dan Riset Edisi 


\section{REGULATED LEARNING}

Ketiga Jilid 1. Alih Bahasa: Fransiska Dian Ikarini. Jakarta: Erlangga.

Hamalik, O. (2005). Proses Belajar Mengajar. Jakarta: Bumi Aksara.

Hurlock, E. B. (2001). Psikologi Perkembangan Suatu Pendekatan Sepanjang Rentang Kehidupan. Edisi Kelima. Penerjemah Instiwidayanti dan Soedjarwo. Jakarta: Erlangga

Inayah, E. R. . (2013). Motivasi Berprestasi Dan Self Regulated Learning. Jurnal Online Psikologi. 01 No. 02. 642-656.

Latipah, E. (2010). Strategi Self Regulated Learning dan Prestasi Belajar: Kajian Meta Analisis. Jurnal Psikologi. Vol 37. 110 - 129.

Martinez-Pons, M. (2009). Test of a Model of Parental Inducement of Academic Selfregulation. The Journal of Experimental Education. 64. 213-227.

Martinez-Pons, M. (2002). A Social Cognitive View' of Parental Influence on Student Academic Self Regulation. Theory Into Practice. 61. 126-131.

Muharrani, T. (2012). Hubungan Antara SelfEfficacy dengan Self Regulated Learning Pada Mahasiswa Fakultas Psikologi USU. Skripsi. (tidak diterbitkan). Medan: Fakultas Psikologi Universitas Sumatra Utara.
Sarafino. (1994). Health Psychology Biopsychosocial Interaction. USA: John Wiley \& Sons.

Smet, B. (1994). Psikologi Kesehatan. Bandung: Grasindo.

Sutikno, S. (2004). Menuju Pendidikan Bermutu. Mataram: NTP Press.

Valle, A., Núñez, J.C., Carlos, J., Cabanach, R.G., González Pienda, J.E., Rodríguez, S., Rosario, P., Cerezo, R., \& Muñoz Cadavid, M.A. (2008). Self-regulated Profiles and Academic Achievement. Psicothema. 20. 724-731

Veleyutham, S. et al. (2012). Gender Differences In Student Motivation And Self-Regulation In Science Learning:A Multi-Group Structural Equation Modeling Analysis. Journal of Science and Mathematics Education. 13471368.

Zimmerman, B.J., \& Martinez-Pons, M. (1988). Construct Validation of a Strategy Model of Student Self-regulated Learning. Journal of Educational Psychlogy. 80. 284-290.

Zimmerman, B.J., \& Martinez-Pons, M. (2001). Students Differences in Self Regulated learning: Relating Grade, Sex, and Giftedness to Self Efficacy and Strategy use. Journal of Educational Psychology. 82. 51-59. 